\title{
The Immunogenicity and Protective Efficacy of DNA Vaccine Coding for NA1 Gene of Highly Pathogenic Avian Influenza H5N1 Subtype Soliman YA ${ }^{1}$, Maha AN Gamal ${ }^{1}$, Eman M.S. Elnagar ${ }^{* 2}$ and Khalil S. ${ }^{3}$ \\ ${ }^{1}$ Central Laboratory for Evaluation of Veterinary Biologics, Abassia, Cairo, Egypt. \\ ${ }^{2}$ Veterinary Serum and vaccine research institute, Abassia Cairo, Egypt. \\ ${ }^{3}$ Faculty of Vet. Med. Alex. University, Egypt. \\ *Corresponding Author, Eman M.S. Elnagar, E-Mail: emanalnagar81@gmail.com
}

\begin{abstract}
Control of avian influenza infection depends mainly on biosafety measures and vaccination, DNA vaccination is a novel method to generate antigenspecific antibody and cell-mediated immunity. In the current study, a DNA vaccine for full-length $\mathrm{N} 1$ gene was developed in a trial to decrease the severity of avian influenza virus spread and shedding. Full-length N1 gene was cloned in entry clone $p$ ENTER SD/TOPO, followed by homologous recombination with the destination mammalian expression vector (PDEST 40). The PDEST 40-N1 was used in the immunization of SPF chickens. Potency was evaluated through the survival rate that reaches $65 \%$, which was far less than the commercially available inactivated vaccine. Meanwhile, the shedding of the virus from dead birds was $0.46 \log 10 \mathrm{EID}_{50}$. At the same time, the most surprising result was the shedding level of the vaccinated live birds that were zero shedding ; on the other hand, the inactivated vaccine could not reduce the shedding level which remains very high $(3.2 \log 10$ EID50 ). IFN- $\gamma$ transcript level in the DNA vaccinated group was detected by the $3^{\text {rd }}$-day post-vaccination and remained upregulated till the $28^{\text {th }}$ postvaccination. After the challenge, the level of IFN- $\gamma$ was much higher until 14 days post-challenge. The inactivated vaccine could not stimulate any detectable level post-vaccination. These data suggested the ability of DNA vaccine coding for $\mathrm{N} 1$ gene of avian influenza to combat the virus shedding from live birds and could be used in combination with DNA vaccine coding for $\mathrm{H} 5$ to produce maximum protection with zero shedding.
\end{abstract}

Keywords: avian influenza; haemagglutinin gene; neuraminidase gene; DNA vaccine, N1
Original Article:

DOI: HTTPS://DX.DOI.ORG/10.2

1608/JAVS.2020.85638

Received:06 April, 2020.
Accepted :25 April, 2020.
Published in April, 2020.

This is an open access article under the term of the Creative Commons

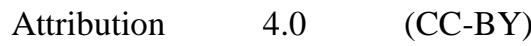
International License . To view a copy of this license, visit http://creativecommons.org/licenses/ by/4.0/

J. Appl. Vet. Sci., 5(2): 109-123.

\section{INTRODUCTION}

Influenza A viruses are enveloped segmented negative-sense single-stranded RNA genome belonging to family Orthomyxoviridae. The member of this family is clustered antigenically and genetically into different subtypes based on the two surface glycoproteins hemagglutinin HA (16 subtypes) and neuraminidase NA (9 subtypes) (Harris, et al., 2017 and Fouchier, et al., 2005). These are expressed in numerous combinations of viruses isolated from aquatic avian species, and an additional two combinations, H17N10 and H18N11, have been identified in bats (Tong, et al., 2013). Furthermore, Type-A NAs are subdivided into two phylogenetically distinct groups. Group-1 (NA 1, 4,
5 and 8), whereas group-2 (NA 2, 3, 6, 7, and 9) (Kim, et al., 1997).

The NA is an integral membrane protein belonging to Glycoside hydrolase family which has one known activity; sialidase or neuraminidase that cleaves the terminal sialic acid residues at its $\alpha$-ketosidic linkage to adjacent sugar residues these sialic acid receptors found in the mucin lining most the epithelial tissues allowing the virus to penetrate through mucus secretions to reach target cells. Also, it prevents virus self-aggregation by removing the carbohydrate from the viral envelope thus facilitating the mobility of the virus to and from the site of infection and enhance viral release (McAuley, et al., 2019). 
NA is a homotetramer with an enzymatic head and a stalk which is the transmembrane protein domain that inserts within the viral envelope. The hydrophilic tail consists of six amino acids, MNPNQK, and is highly conserved in most type A influenza viruses except for some swine-origin N1 genes, his sequence is involved in the morphology of influenza viruses, with mutations in NA containing no tails resulting in a higher percentage of viruses in the filamentous shape (Barman, et al., 2004). The gene encoding NA is approximately 1,413 nucleotides long and codes for a protein of around 470 amino acids which has at least five potential glycosylation sites (Blumenkrantz, et al., 2013). The size of the protein differs between NA subtypes and even within viruses from the same subtype.

The NA glycoprotein is immunogenic, but not all antibodies generated against it can inhibit its function. Antibodies generated against the NA enzymatic site produce the highest amount of neuraminidase inhibitory (NI) activity, as defined by the ability of antibodies to block NA enzymatic function (Sylte and Suarez 2009). Anti-NA antibodies have been underestimated, due to the main role that played by HA in influenza virus researches. Many data have been suggested the role of Anti-NA that can induce protection against the influenza infection, recently Chen et al., 2018 found that anti-NA Abs were present in humans after an influenza infection also seasonal vaccination induces a poor NA-specific B-cell response, whereas anti-NA B-cell responses after influenza infection are similar $(\mathrm{H} 1 \mathrm{~N} 1)$ or even higher (H3N2) when compared to HA-specific B-cell responses.

The effector mechanism of NI activity responsible for protecting mammals or birds from influenza is not precise but appears to differ from antibodies directed against the HA protein. One likely mechanism is that the NI activity keeps influenza viruses trapped on the apical surfaces of infected cells, where they may be susceptible to cytotoxic $\mathrm{T}$ lymphocyte (CTL) or NK-mediated killing. Although CTLs readily kill influenza-infected cells in vitro ( Guo, et al., 2011) and the respiratory tracts of mice and humans (Flynn, et al. 1999; Wiley, et al. 2001),

Some investigations revealed that DNA vaccine encoding full-length N1gene of HPAI could result in the development of protective immune response against lethal challenge with the virulent AI strain. In most cases, two or three doses of naked plasmid DNA are required to induce an immune response to the pathogen (Leitner, et al., 1997). Nevertheless, other studies have shown that a single dose of DNA vaccine can trigger protective immunity which demonstrated the high potential of DNA vaccine as an alternative to the inactivated vaccines (Lima, et al., 2003, Jalilian, et al., 2010).

The current study aimed to produce a DNA vaccine coding for the NA1 gene of HPAI H5N1 subtype and evaluation of the humoral and cellmediated immune response as a tool to control avian influenza infection in Egypt.

\section{MATERIALS AND METHODS}

All applicable international, national and/or institutional guidelines for the care and use of animals were followed. This article does not contain any studies with human participants performed by any of the authors.

\section{Avian influenza virus}

Egyptian field isolate of HPAI subtype H5N1 was isolated from Qalubia governorate during winter 2017, purified and completely identified using HA, HI, PCR and sequencing and assigned as (A/chicken/Qalubia/ch1.12.61/2017 (H5N1)). The isolate was propagated in embryonated chicken eggs (911 day old), this strain used for DNA vaccine coding for the full-length NA1 preparation and challenge test.

\section{Amplification of the full-length NA1 gene}

HPAI H5N1 subtype (A/chicken/Qalubia/ ch1.12.61/2017 (H5N1)) was propagated in the chorioallantoic fluid of SPF-ECE, after embryonic deaths (usually within $18 \mathrm{~h}$ ), the chorioallantoic fluid was collected and purified by centrifugation at $14000 \mathrm{rpm} / 5 \mathrm{~min}$. Viral RNA was extracted from the clarified Allantoic fluid (Sambrook, et al., 1989), by QIAamp Viral RNA Mini Kit (Qiagen Germany, cat \#52904), according to the manufacturer's instructions.

The full-length N1 genes were amplified by two steps RT-PCR. First, the cDNA was synthesized using M-MuLV First Strand cDNA Synthesis Kit (Biomatik cat \# K5147) according to the manufacture instruction. Briefly, $5 \mu 1$ of the viral RNA (containing either 50 or $25 \mathrm{ng}$ ) was incubated at $65^{\circ} \mathrm{C} / 5 \mathrm{~min}$ with $100 \mathrm{nM}$ of each sense primer (table 1) and $1 \mu 1$ of dNTP (10 moles each) in a volume of $14.5 \mu 1$. The mixture was then incubated on ice $/ 5$ min then $1 \mu$ l of $5 \mathrm{X}$ RT buffer, 40 IU of RNase inhibitor and 200 IU of MMuLV reverse transcriptase enzyme was added. The reactions were incubated at $25^{\circ} \mathrm{C} / 5 \mathrm{~min}$ then at $42^{\circ} \mathrm{C} / 60$ $\min$. The reverse transcriptase was deactivated by incubation at $85^{\circ} \mathrm{C} / 5 \mathrm{~min}$.

Second step PCR was done using Pfu Ultra II Hotstart PCR Master Mix (Agilent USA cat \# 600850). Fife microliter of the cDNA was included in each 
reaction using full orf of N1 genes (Table 1) The primers were designed and verified by Lasergene DNAStare software V 15 using the full-length orf N1 sequences of avian influenza H5N1 Egyptian isolates retrieved from the gene bank database. The amplicons were electrophoresed on a $1 \%$ agarose, and the size of the amplicons was determined using SynGene tool software V4.01 (SynGen Corporation, Cambridge, England)

\section{Sequencing of the full-length NA1 gene}

The complete nucleotide sequences of fulllength N1 genes were performed in (Macrogen USA). For the preparation of the gene for sequencing, the PCR products were separated on $1 \%$ low melting agarose. The bands were sliced off and purified with the biospin PCR purification kit (Biobasic cat \# BSC03S1) as described by the manufacture. Sequencing reactions were performed in an MJ Research PTC-225 Peltier Thermal Cycler using ABI PRISM 3730XL Analyzer BigDyeTM Terminator Cycle Sequencing Kits with AmpliTaq DNA polymerase (FS enzyme Applied Biosystems), following the protocols supplied by the manufacturer. Single-pass sequencing was performed on each template using the primer used for PCR amplification. The fluorescent-labelled fragments were purified from the unincorporated terminators with an ethanol precipitation protocol. The samples were resuspended in distilled water and subjected to electrophoresis in an ABI 3730xl sequencer (Applied Biosystems).

\section{Generation of the mammalian expression vector (DNA vaccine) coding the full N1 gene}

The amplified full-length $\mathrm{N} 1$ gene was cloned in the donor vector using pENTR ${ }^{\mathrm{TM}}$ Directional ( $p E N T R / S D / D-T O P O)$ Cloning Kits (life technologies USA Cat \# K2420-20) according to the manufacture instructions, followed by the transformation in TOPO 10 E.coli and inoculated on LB-Kanamycin agar and incubated overnight at $37^{\circ} \mathrm{C}$. Transformants were subcultured on LB broth-kanamycin $(50 \mathrm{ng} / \mathrm{ml})$ at $37^{\circ} \mathrm{C}$ in a shaker incubator at a speed of $150 \mathrm{rpm} / 24 \mathrm{~h}$. (Soliman, et al., 2016).

QPCR analyzed the transformants for the presence of the gene of interest. Briefly, the plasmid DNA was extracted from the overnight culture using Pure Link. HQ Mini Plasmid Purification Kit (Invitrogen Cat. \# K2100-01). Ten ng of the DNA plasmid was mixed with $12.5 \mu \mathrm{l}$ of the Brilliant II QPCR Master Mix (Agilent Cat \# 600804), 100nM of each of the forward and reverse primers (Table 1) and 200nM of the dual labelled probe. The program was adjusted at $95^{\circ} \mathrm{C} / 10$ min initial denature then 40 cycles at $95^{\circ} \mathrm{C} / 30$ sec, annealing at $58^{\circ} \mathrm{C} / 30 \mathrm{sec}$ and extension at $72^{\circ} \mathrm{C} /$ $30 \mathrm{sec}$.

Transformants that give positive $\mathrm{C}_{\mathrm{t}}$ ( indicating the presence of $\mathrm{N} 1$ gene insert ) were further subcultured on LB-broth-kanamycin and plasmids were purified and subjected to homologous recombination with the Gateway pcDNA-DEST40 vector (life technologies USA Cat \# 12274-015) according to the manufacture instructions. Recombinant destination vector carrying N1 (pDEAST40/N1) gene was transformed in TOPO 10 E.coli, cultured on LBampicillin $(100 \mathrm{IU} / \mathrm{ml})$ overnight at $37^{\circ} \mathrm{C}$. Growing colonies were sub-cultured overnight on LB-ampicillin broth in shaker incubator and tested for the presence of N1 genes using QPCR as before.

\section{Preparation of the DNA vaccine coding for the full- length NA1 gene}

A single colony of E.coli harboring the destination vector carrying $\mathrm{N} 1$ genes were picked up in $10 \mathrm{~mL}$ of LB broth containing $100 \mathrm{IU} / \mathrm{mL}$ ampicillin and incubated overnight at $37^{\circ} \mathrm{C}$ with agitation (200rpm) in shaker incubator. The whole culture was added to 1 litter LB broth with antibiotic and incubated as before. The culture was then cooled down on the ice and subjected to plasmid purification using Maxi prep kit (BioBasic cat \# BS466). The plasmid preparation (DNA vaccine) was quantified using Qubit ${ }^{\circledR}$ dsDNA BR Assay Kit (Life technologies Cat\# Q32850). The concentration was adjusted at $1 \mu \mathrm{g} / \mu \mathrm{l}$ and stored at $20^{\circ} \mathrm{C}$ till used for vaccination.

\section{Experimental design}

\section{Chickens immunization with DNA vaccine coding full-length $\mathrm{N} 1$ gene}

Three weeks old, White Leghorn SPF chickens (Nile-SPF-eggs farm, Koom Oshiem, Fayum, Egypt) were housed in closed system Bio-isolators with sterilized food and water supply. The chickens were divided into three groups and vaccinated as in table (2). At the day 28 of vaccinations chicken challenged with $0.2 \mathrm{~mL}$ (virus titer $=6 \log 10 \mathrm{EID}_{50}$ ) of the challenging virus strain (A/chicken/Qalubia/ch1.12.61/2017 (H5N1)) via eye drop route.

\section{Sampling}

Heparinized blood samples were taken to measure the level of the IFN-y transcript at days 3, 5, 7 15,28 post-vaccination (before challenge) and 3, 7 and 14 days post-challenge from live birds. Cloacal swaps were taken from life birds 14 days post-challenge and when possible from the recently died chickens. 


\section{Evaluation of the DNA vaccine coding for full-length N1 gene}

\section{Protection rate}

The protection rate was calculated 14 days postchallenge using the equation:

Protection percentage $=($ total number of bird in a group- number of dead birds / total number of birds) X100

\section{Shedding test}

Cloacal swabs were swirled in $1 \mathrm{~mL}$ of sterile saline, and the titer of the viral shedding was measured using $\mathrm{EID}_{50}$ (Reed and Meunch 1938).

\section{IFN- $y$ transcript quantitation using qRT-PCR}

\section{Purification of Avian influenza protein antigen}

The viral proteins of (A/chicken/Qalubia/ ch1.12.61/2017 (H5N1)) strain were purified using Trizol Reagent (Invitrogen cat No 15596026) according to the manufacture instructions. The purified protein was resuspended in CAHPS and the concentration of the protein was measured using Qubit II assay (Invitrogen Cat \# Q33211) and adjusted at $5 \mu \mathrm{g} / \mathrm{ml}$. The protein preparation kept in aliquots in Low bind polypropelling tubes at $-80{ }^{\circ} \mathrm{C}$ till used.

\section{Purification of peripheral blood mononuclear cells (PBMCs) from chicken groups}

Three milliliters of heparinized blood was diluted 1:1 with sterile PBS pH7.2, and the PBMCs were separated by density-gradient centrifugation using Ficoll-Paque (density, $1.077 \mathrm{~g} / \mathrm{ml}$; biowest cat\# L0560500) and washed twice with RPMI 1640 medium (Invitrogen, Burlington, Ontario, Canada). The PBMCs were diluted in RPMI 1640 containing $10 \%$ fetal calf serum (Invitrogen) and supplemented with penicillin $\mathrm{G}$ and streptomycin $(100 \mathrm{U} / \mathrm{ml}$ and $100 \mathrm{mg} / \mathrm{ml}$, respectively) and then counted using trypan blue dye exclusion assay and adjusted at $1 \times 10^{6} / \mathrm{ml}$. Cells were dispensed in 96 well tissue culture plate $(200 \mu 1 /$ well $)$.

To induce the IFN- $\gamma$ transcript, the cells were pulsed with either $10 \mu \mathrm{l}$ of avian influenza protein (a specific stimulant) or $10 \mu \mathrm{l}$ of Phyto-haemagglutinin (PHA) at a concentration of $10 \mu \mathrm{g} / \mathrm{ml}$ (nonspecific positive control stimulant) or with PBS (unstimulated negative control cells). The cells incubated at $37^{\circ} \mathrm{C} / 20$ $\mathrm{h}$ in $5 \% \mathrm{CO} 2$ incubator. After $20 \mathrm{~h}$, the cells were harvested and the total cytoplasmic RNA was purified using Trizol reagent according to the manufacture instructions. All RNA samples were treated with RNase-free DNase I (Qiagen cat\# 79254) to remove any traces of genomic DNA contamination.

\section{Quantitation of the IFN- $\gamma$ transcript}

The level of IFN- $\gamma$ mRNA from cultured PBMCs either pulsed with avian influenza proteins or the un-pulsed culture was measured using Q-PCR assay (Yeong, et al., 2014 and Pete, et al., 2003).

Total RNA was reverse transcribed to cDNA with the Omniscript cDNA Synthesis kit (Qiagen Cat \# 205111). Briefly, approximately 50ng of the purified total RNA was reverse transcribed in a final volume of $20 \mu 1$ of reaction mix containing 1X RT buffer, dNTPs $\operatorname{mix}(5 \mathrm{mM}$ each), ribonuclease inhibitor $(10 \mathrm{U} / \mathrm{ml})$, and $4 \mathrm{U}$ of Omniscript RT enzyme. The samples were incubated at $37{ }^{\circ} \mathrm{C}$ for $60 \mathrm{~min}$. For genomic DNA contamination control, every reaction set contained an RNA sample without Omniscript RT enzyme (negative RT reaction), which was carried forward into subsequent PCR reactions. The resulting CDNA was stored frozen $\left(-80^{\circ} \mathrm{C}\right)$ until assayed by real-time PCR.

The real-time PCR reaction mixture contained $5 \mu 1$ of sample cDNA in $20 \mu$ final reaction volume containing $200 \mathrm{nM}$ of the probe and $100 \mathrm{nM}$ each of forward and reverse primers (sequence shown in table 2), and $1 \mathrm{X}$ of the brilliant II QPCR master mix (Agilent cat \# 600804). The $5 \mu 1$ volume of cDNA sample was added to the initial reaction mixture as a 1:2 dilution of the RT reaction in DNase/RNase-free water. Each set of reactions also included negative controls (i.e., water instead of cDNA sample). The reaction was run on Agilent MX3005P instrument using the following cycling parameters: Initial activation of Taq DNA polymerase in the PCR core reagent, and denaturation of DNA, all at $95^{\circ} \mathrm{C} / 10 \mathrm{~min}$; and then 40 cycles of denaturation at $95^{\circ} \mathrm{C} / 20 \mathrm{sec}$ and annealing with primer at $50^{\circ} \mathrm{C} / 20 \mathrm{sec}$ and extension at $60^{\circ} \mathrm{C} / 45 \mathrm{sec}$, with the fluorescence data being collected at the end of the extension step.

Optical data obtained by real-time PCR were analyzed using the default parameters available with the MX pro 3005P software (Agilent). The PCR threshold cycle number $\left(\mathrm{C}_{\mathrm{t}}\right)$ for each tested cDNA sample was calculated at the point where the fluorescence exceeded the threshold limit. The threshold limit was fixed along with the linear logarithmic phase of the fluorescence curves at ten standard deviations above the average background fluorescence. The average $C_{t}$ for duplicate samples was calculated.

$\beta$ actin genes were used as housekeeping nonregulated reference genes for normalization of target gene expression. The results were analyzed using the Livak method. Relative transcript abundance of the IFN- $\gamma$ gene equals $\Delta \mathrm{Ct}$ values $\left(\Delta \mathrm{Ct}=\mathrm{C}_{\mathrm{t}}\right.$ target $-\mathrm{C}_{\mathrm{t}}$ reference). Relative changes in the transcript were expressed as $2^{-\Delta \Delta \mathrm{Ct}}$ values (Schmittgen and Livak 2008). 


\section{Soliman Y.A. et al.}

\section{Analysis}

DNA sequencing and phylogenetic tree construction were made using CLC- workbench V10. Protein antigenicity and cell epitope mapping were done using DNAStare software V15. The statistical analysis was done using SPSS V21. ANOVA test with LSD as post hook analysis was used to calculate the sig value at $95 \%$ confidence interval. The relative gene expression analysis was done using REST 2009 software.

\section{RESULTS}

\section{Construction of the mammalian Amplification and sequence analysis of the full-length orf of the N1 gene}

The full-length N1 (orf) gene was amplified (fig 1) from the SPF-ECE propagated isolate (A/chicken/Qalubia/ch1.12.61/2017 (H5N1)). A visible band migrating about 1400 bp was seen when RNA concentration was 50ng/ reaction. Sequencing and phylogenetic tree analysis of N1 (Fig 2\&3) revealed that the strain used in the current study had identified more than $98 \%$ with most Egyptian isolates included in the construction of the phylogenetic tree. Those isolates were divided into two groups with substitutions $<0.015$ the first group including (A/chicken/Qalubial ch1.12.61/2017 (H5N1)) and the EU16883.1 (this isolate belong to the classical HPAI isolated back to 2006. The second group contain most isolates covering the year 2010-2018. Immunogenicity profile of the deduced amino acid sequence revealed that there is about 17 major antigenic determinant with an index above 2.5 that have both B-cell and T-cell epitopes. Other minor regions have also been predicted but with lesser threshold.

\section{Expression vector for the full orf $\mathrm{N} 1$}

The full-length N1 gene was firstly cloned into pENTER/ SD/D Topo entry vector that grown in Topo 10 Ecoli, purified and entirely quantitated using qPCR assay Fig (5 A). Homologous recombination between the first construct and the destination vector PDEST 40 was successfully done fig $(5 \mathrm{~B})$. This pDEST $40-\mathrm{N} 1$ is the mammalian expression DNA vaccine that will be used in chicken immunization.

\section{Evaluation of the DNA vaccine}

After challenge with (A/chicken/Qalubia/ ch1.12.61/2017 (H5N1)). Chickens from G1 (vaccinated with the pcDEAST40/N1 DNA vaccine) showed no sign of disease within the first four days post-challenge. The birds remained healthy, active with eating and drinking rates normal. Nevertheless, by the day five birds became inactive with reduced food intake. Deaths began by the end of the 7th day, but the dead chicken showed no growth lesions. P/M examination showed very hemorrhagic foci on the coronary fat and the tracheas were slightly hemorrhagic when compared with dead birds from the non-vaccinated group. The survival rate in this group was $65 \%$ (deaths were at day $7-10$ ). Chickens in G2 ( vaccinated with inactivated vaccine ) showed more resistance to the challenge, as deaths begin five days post-challenge but with a lower rate than G1 ( survival rate $\sim 85 \%$ ), nevertheless, the $\mathrm{P} / \mathrm{M}$ examination showed more severe lesions on cardiac coronary fat and the tracheas were severally haemorrhagic. Chickens from the control group (G3) have died within three days after challenge with signs and PM lesion typical for the HPAI infection.

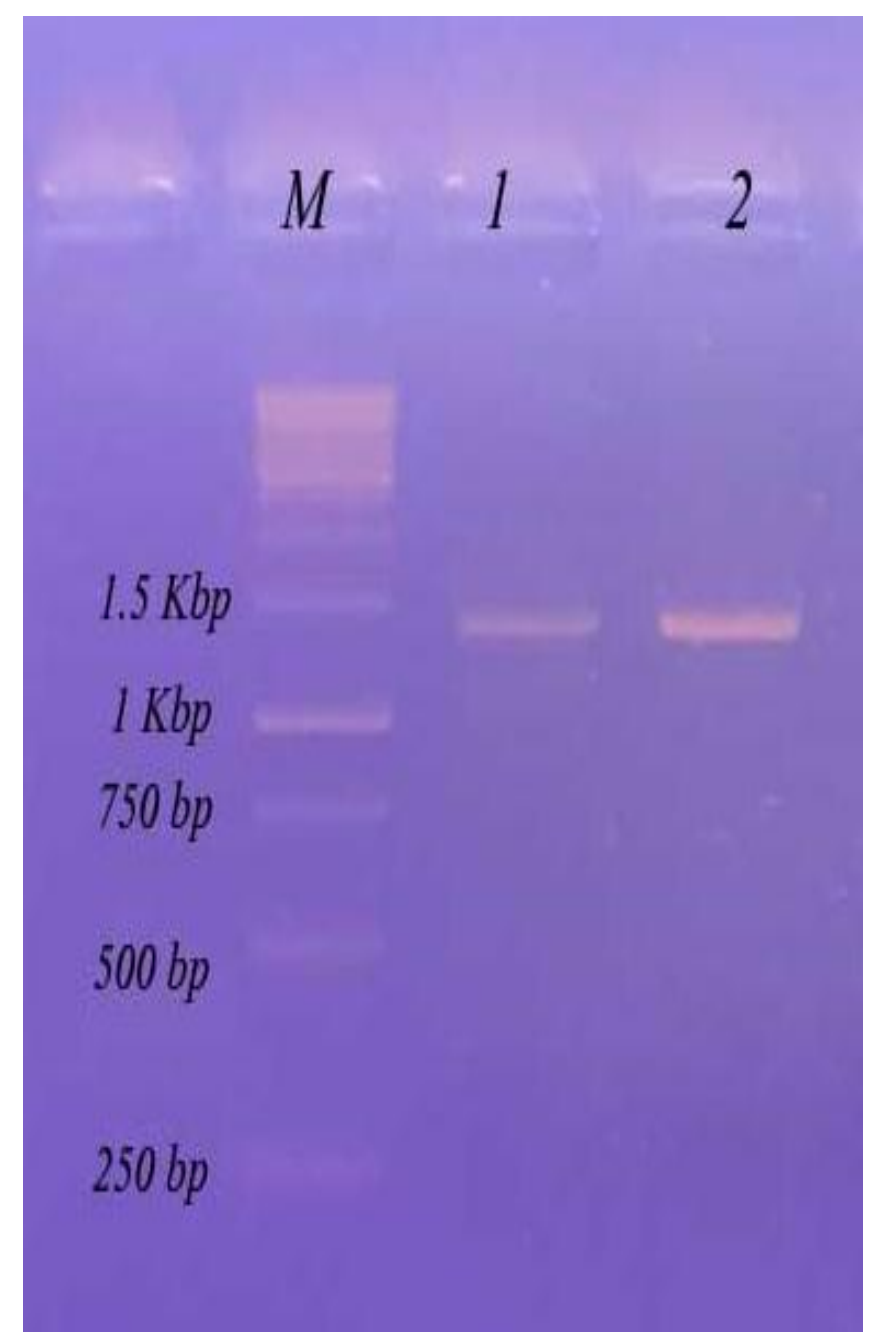

Fig. 1: amplification of full-length $\mathrm{N} 1$ gene from (A/chicken/Qalubia/ch1.12.61/2017 (H5N1)) isolate. A clear visible band migrating at $\sim 1400$ bp was seen when using 50ng of RNA per reaction (lane 2) while lower concentration (25 ng) gave faint band (lane 1). M DNA ladder. 
Tables 1: The sequences of primers used in the current study

\begin{tabular}{|c|c|c|}
\hline Target gene & Primer Sequence (5'- 3') & Ref \\
\hline \multirow{2}{*}{$\begin{array}{l}\text { full-length } \\
\text { N1 gene }\end{array}$} & AI-N1-f $\quad 5^{\prime}-\underline{\text { CACCATGAATCCAAATCAGAAGATAAT- }{ }^{\prime}}$ & \multirow[t]{2}{*}{ This study } \\
\hline & AI-N1- r 5' - CTTGTCAATGGTGAATGGCAACT - 3' & \\
\hline QPCR for & NA-f $5{ }^{\prime}$ - GTCTTTGACAGTCCCRTTGGAGTGC- ${ }^{\prime}$ & \multirow{2}{*}{$\begin{array}{c}\text { Naksupan, } e t \\
\text { al., } 2008\end{array}$} \\
\hline N1 gene & $\begin{array}{ll}\text { NA-r } & 5^{\prime}-\text { ACTACCKGTTCCATCATTGGGGCGT- }{ }^{\prime}\end{array}$ & \\
\hline \multirow{3}{*}{ QPCR IFN-Y } & 5' -GTGAAGAAGGTGAAAGATATCATGGA- 3' & \multirow{3}{*}{$\begin{array}{c}\text { Kaiser, et al., } \\
2003\end{array}$} \\
\hline & 5'-GCTTTGCGCTGGATTCTCA- 3' & \\
\hline & Fam- 5' -TGGCCAAGCTCCCGATGAACGA- 3' -Tamra & \\
\hline \multirow{3}{*}{$\begin{array}{l}\text { QPCR } \\
\beta-\operatorname{actin}\end{array}$} & $\beta$ - actin $\mathrm{f} \quad 5^{\prime}$-CTCCATCATGAAGTGTGACGTT- $3^{\prime}$ & \multirow{3}{*}{$\begin{array}{c}\text { Hong, et al., } \\
2006\end{array}$} \\
\hline & $\beta-\operatorname{actin}-\mathrm{r} \quad 5^{\prime}$-ATCTCCTTCTGCATCCTGTCAG- 3' & \\
\hline & Fam-5' -CAAGGACCTCTATGCCAACACAGTGCT-- 3'Tamra & \\
\hline
\end{tabular}

NB. The bold, underline nucleotide sequence was added to facilitate the directional cloning in the pENTER $\mathrm{SD} / \mathrm{D}$ topo donor vector.

Table 2: The vaccination program and doses of the experimental infection study

\begin{tabular}{|llc|}
\hline Group & Symbol & Vaccine type and dose \\
\hline Group one & G1 & $0.5 \mathrm{~mL}$ I/M of DNA vaccine containing \\
(15 birds) & & $50 \mu \mathrm{g}$ (pDEAST40/N1) \\
\hline Group two & G2 & Commercially inactivated oil adjuvented avian influenza vaccine \\
(15 birds) & & $0.5 \mathrm{~mL} /$ bird $/ \mathrm{M}$ \\
\hline Group three & G3 & $0.5 \mathrm{~mL}$ saline as a non-vaccinated group (control) \\
(10 birds) & & \\
\hline
\end{tabular}




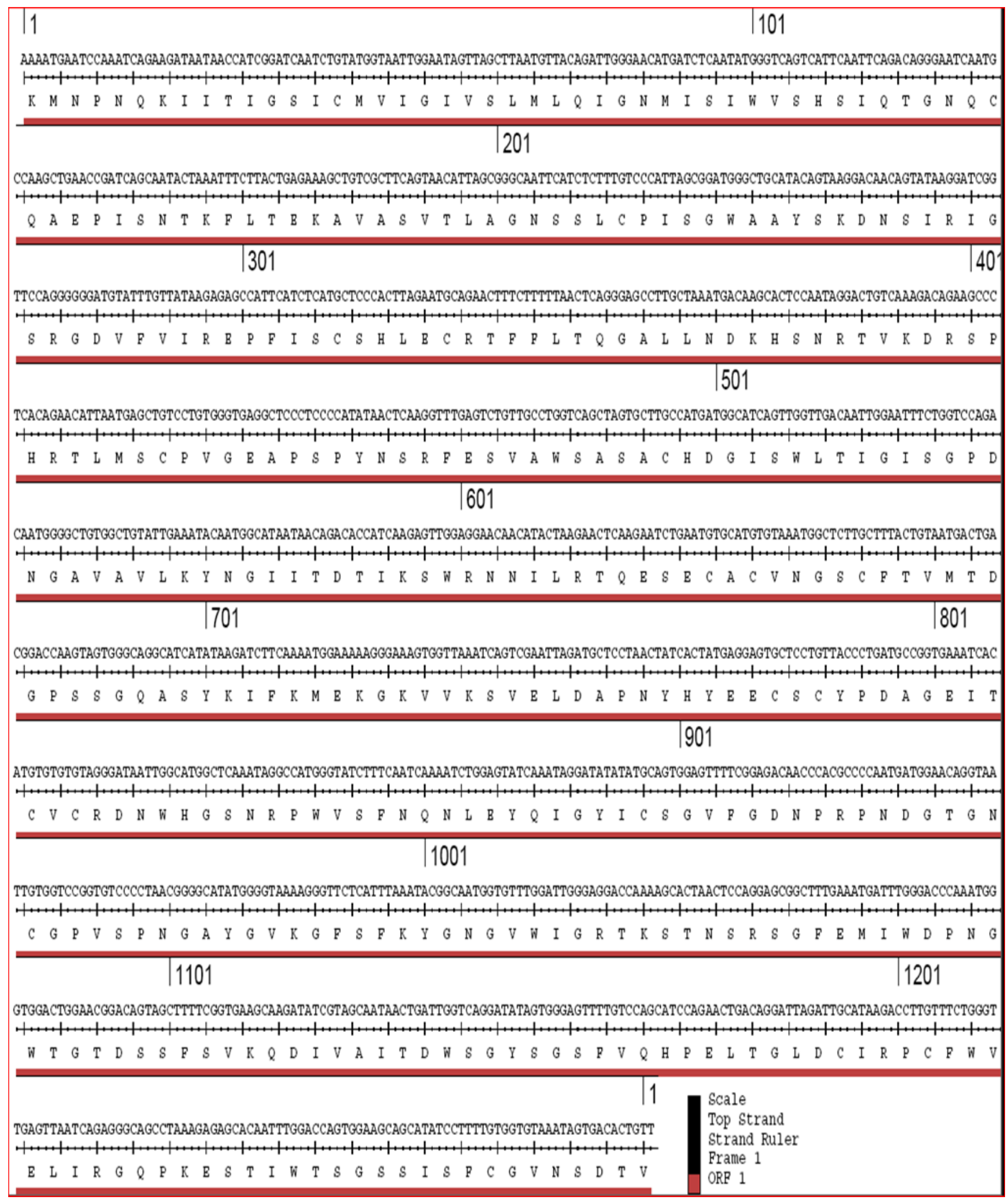

Fig.2: The nucleotide and deduced amino acid sequence of the full-length $\mathrm{N} 1$ gene of (A/chicken/Qalubia/ch1.12.61/2017 (H5N1)) used for DNA vaccine production 


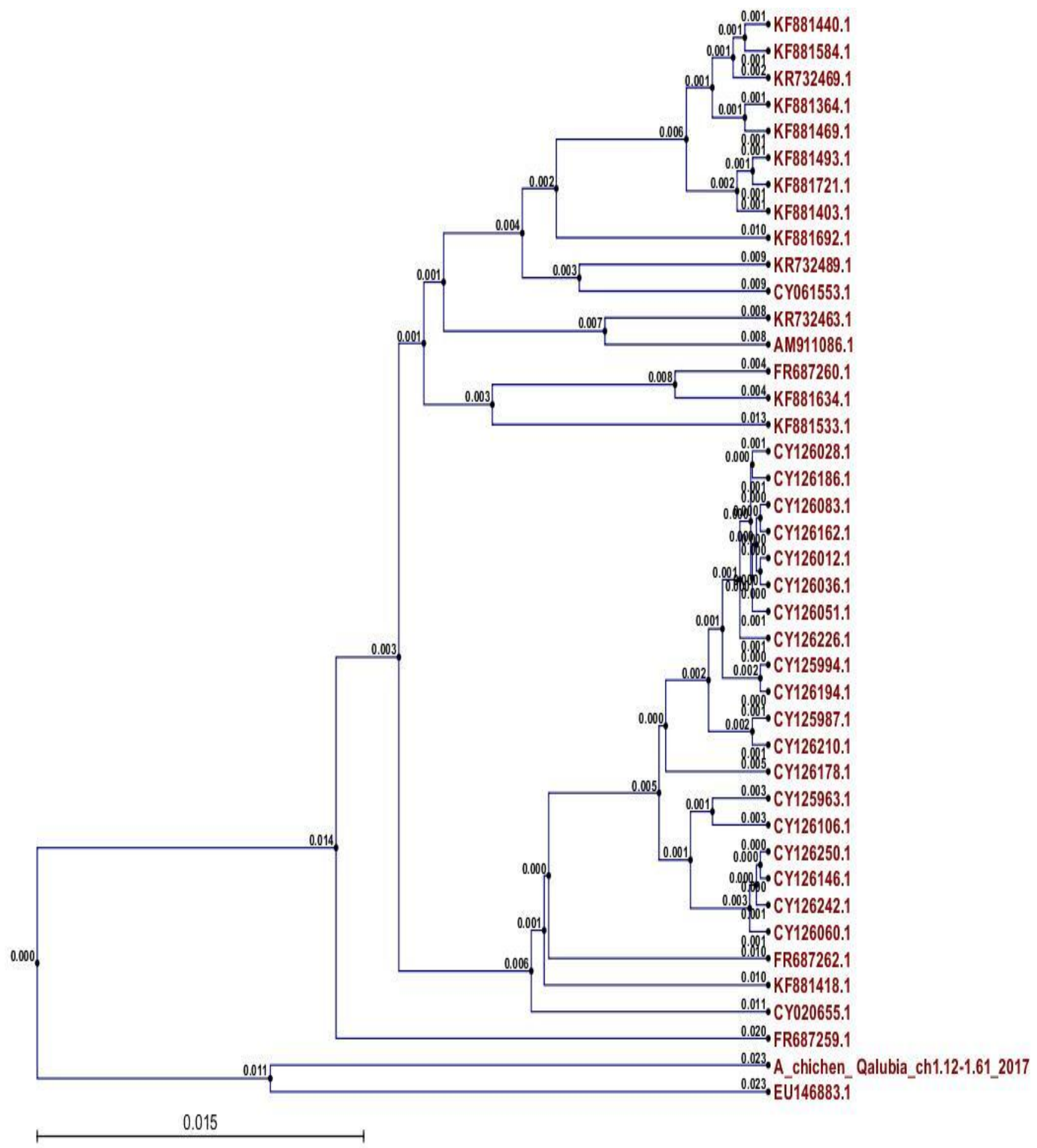

Fig.3: The phylogenetic tree analysis of the (A/chicken/Qalubia/ch1.12.61/2017 (H5N1)) used in the current study and sequences of N1 retrieved from the gene bank database that has an identity of $>95 \%$ and coverage of $100 \%$ 
A

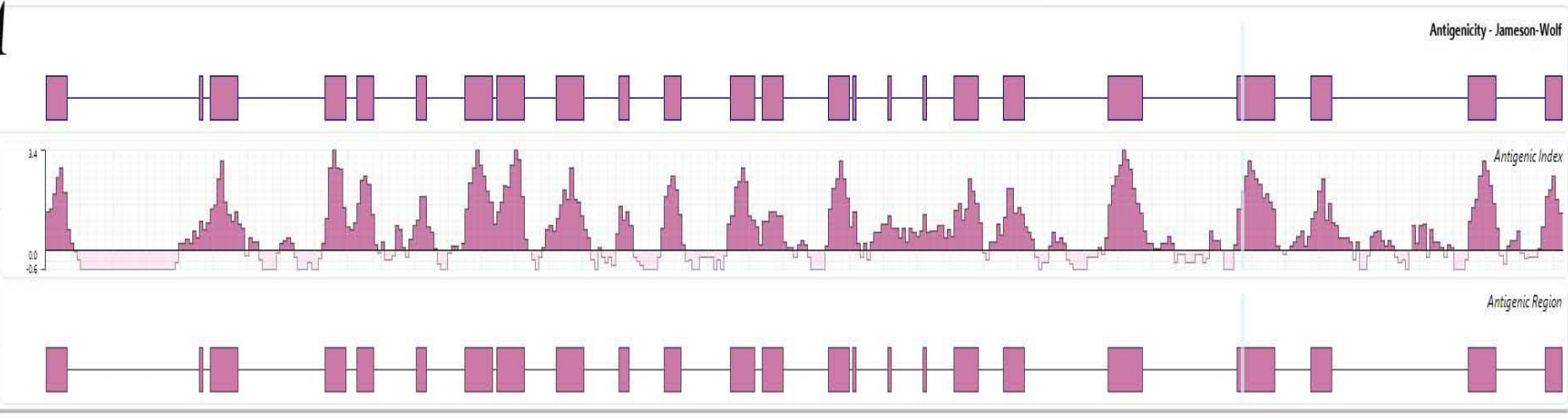

B.cellepitopes - DNASTAR

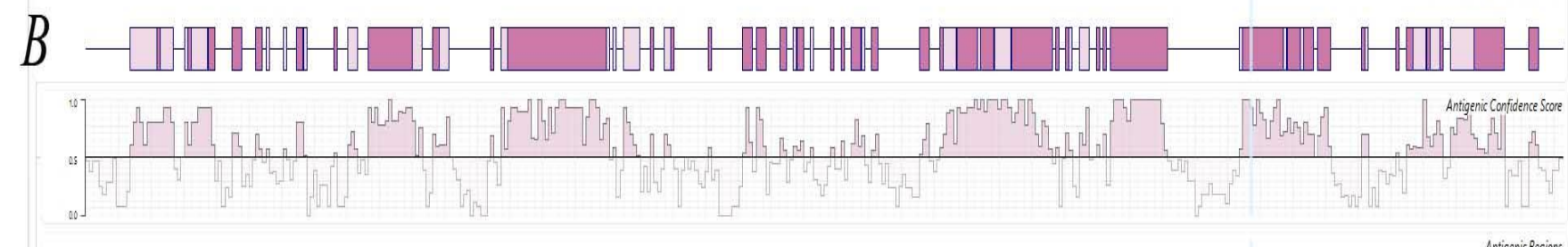

Antigenic Regions

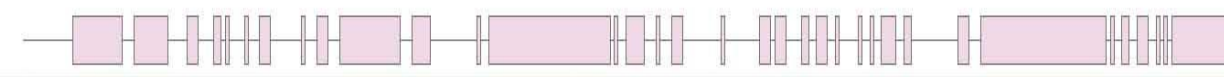

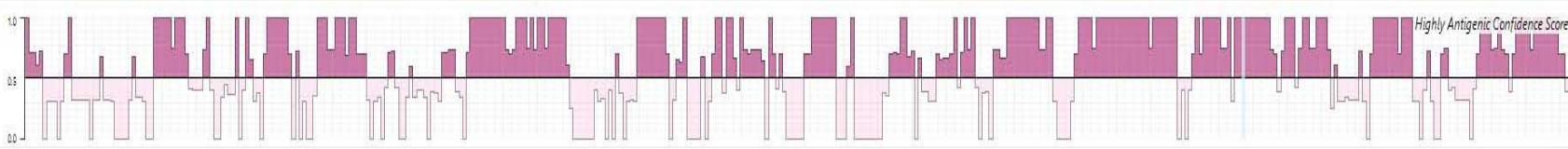

Highy Antigencic Regions

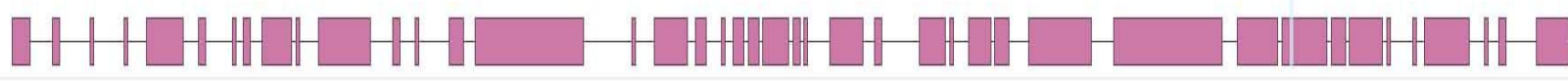

T-cell epitopes-AMPHI

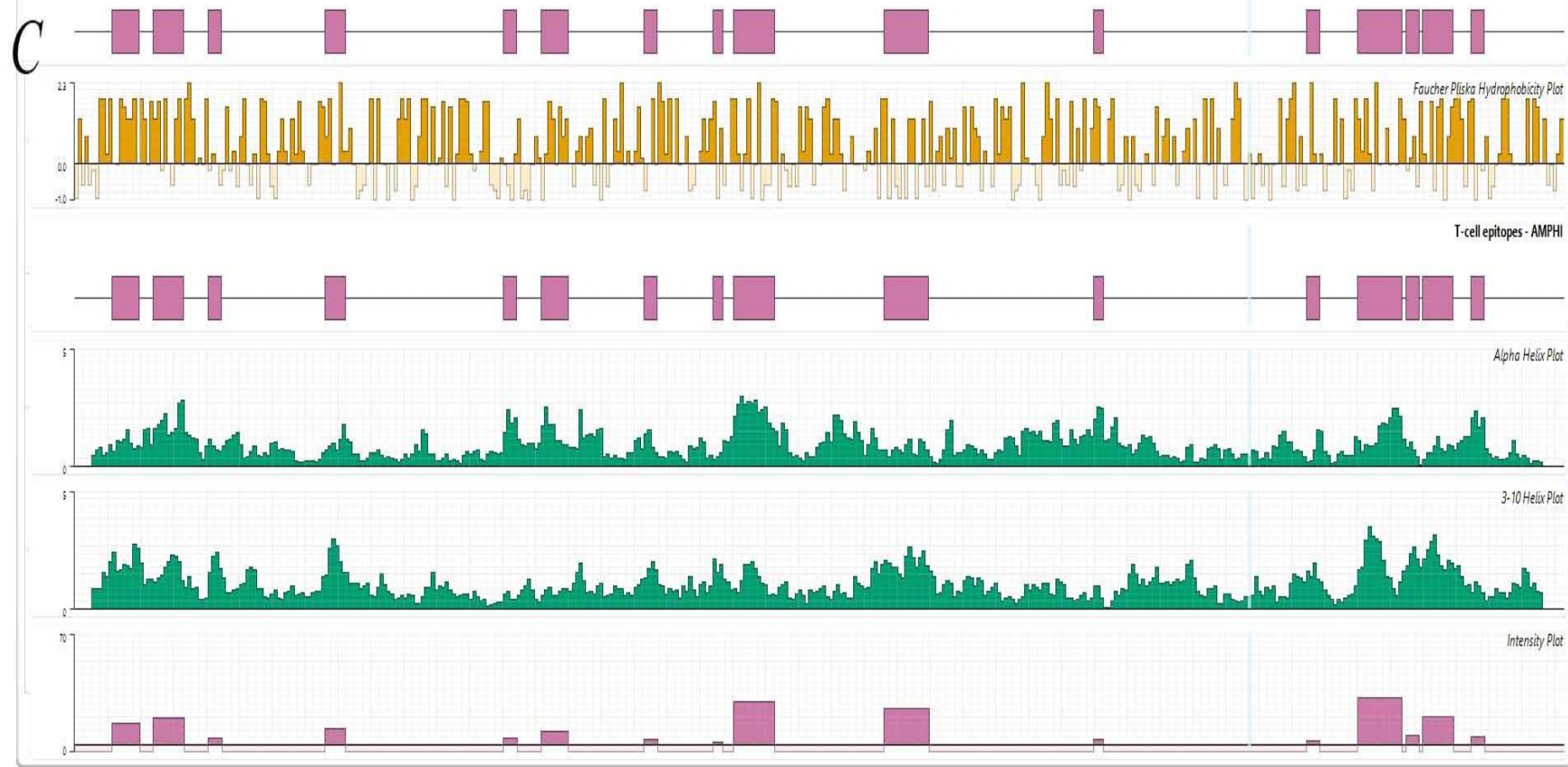

Fig.4: Immunogenic analysis of the deduced amino acid sequence of (A/chicken/Qalubia/ ch1.12.61/2017 (H5N1)) A, the antigenicity profile prediction of the protein, B the B-cell epitope mapping and $\mathrm{C}$ the $\mathrm{T}$-cell epitope mapping of the NA1 protein antigen 


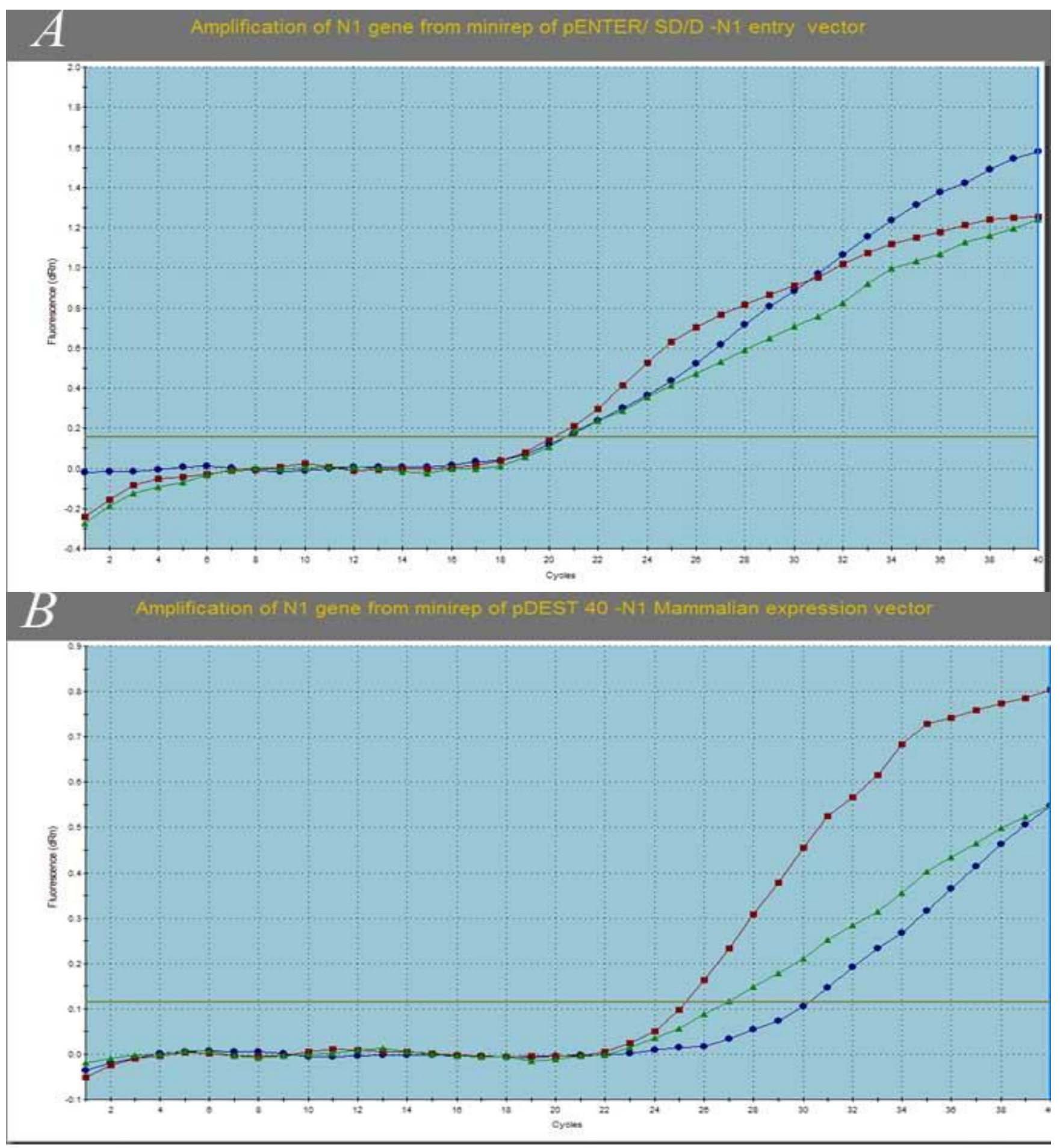

Fig.5:The amplification of the $\mathrm{N} 1$ gene from the entry vector (A) and the mammalian expression vector B).

\section{Shedding}

Cloacal swaps were taken from live birds 14 days post-challenge and from the recently died chickens to measure the shedding level using EID 50. EID $_{50}$ from DNA vaccinated dead birds (G1) showed severe reduction in the shedding level (the mean $\mathrm{EID}_{50}$ was $0.46 \log 10$ ). On the other hand, the live birds showed nearly no level of shedding. (Table 3). Chicken vaccinated with the inactivated commercially available vaccine (G2) showed more level of viral shedding in both the live (the mean $\mathrm{EID}_{50}$ was $3.2 \mathrm{Log} 10$ ) and dead birds (the mean $\mathrm{EID}_{50}$ was $3.25 \log 10$ ). Concerning the unvaccinated control; however, all birds died with $72 \mathrm{~h}$ with mean $\left.\mathrm{EID}_{50}>5.28 \log 10\right)$. 


\section{Measurement of the IFN- $\mathrm{\gamma}$ transcript level}

IFN-y transcript was induced and up-regulated starting 5th-day post-vaccination with the DNA vaccine (G1) and remain sig higher $(\mathrm{P}<0.05)$ till 28 post-vaccination when compared with chickens in $\mathrm{G} 2$ and G3 (Table 4 and fig 6) However after challenge, G1 group showed a sudden increased level of IFN- $\gamma$ transcript by the $3^{\text {rd }}$ days postchallenge which reach its maximum by the 7th-day post-challenge then begin to decline. Yet, it remains significantly higher than the $\mathrm{G} 2(\mathrm{P}<0.05)$. G2 showed a moderate increase of the transcript level by the 3rd-day post-challenge that lasts till the 14th days post-challenge such increase in the transcript level may be due to the infection itself rather than the effect of the inactivated vaccine.

Table 3: The protection rate, the lesions and the shedding level recorded with each group after 14 days of the challenge

\begin{tabular}{|ccccccccc|}
\hline group & Vaccine type & $\begin{array}{c}\text { \% of } \\
\text { deaths }\end{array}$ & $\begin{array}{c}\text { protection } \\
\text { rate } \%\end{array}$ & $\begin{array}{c}\text { Presence } \\
\text { of signs } \\
\text { on dead } \\
\text { birds }\end{array}$ & $\begin{array}{c}\text { Presence } \\
\text { of P/M } \\
\text { lesions }\end{array}$ & $\begin{array}{c}\text { Mean EID 50 of } \\
\text { the shedding }\end{array}$ \\
\hline G1 & pDEAST40/N1 & $7 / 20$ & 65 & - & + & 0 & $\begin{array}{c}\text { Living } \\
\text { birds }\end{array}$ & $\begin{array}{c}\text { Dead } \\
\text { birds }\end{array}$ \\
\hline G2 & $\begin{array}{c}\text { Commercially } \\
\text { available vaccine }\end{array}$ & $3 / 20$ & 85 & ++ & +++ & 3.2 & 3.25 \\
\hline G3 & $\begin{array}{c}\text { Control non } \\
\text { vaccinated }\end{array}$ & $10 / 10$ & 0 & ++++ & ++++ & N & 5.28 \\
\hline
\end{tabular}

$\mathrm{N}$ no bird alive

- $\quad$ No lesions

$+\quad$ Very mild lesions (one sign only externally or internally)

$+\quad$ Moderate lesions (more than one sign)

++++ sever lesions (typical for natural infection)

Table 4; The transcriptional level of the target IFN- $\gamma$ gene expressed as fold change post-vaccination and post-challenge.

\begin{tabular}{|c|c|c|c|c|c|c|c|c|}
\hline \multirow{3}{*}{ 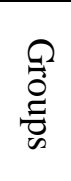 } & \multicolumn{8}{|c|}{ Transcriptional level of the target IFN- $\gamma$ gene expressed as fold change } \\
\hline & \multicolumn{5}{|c|}{ Days post-vaccination(PV) } & \multicolumn{3}{|c|}{ Days post-challenge $(\mathrm{PC})$} \\
\hline & $3 \mathrm{~d}$ & $5 \mathrm{~d}$ & $7 \mathrm{~d}$ & $21 \mathrm{~d}$ & $28 \mathrm{~d}$ & $3 \mathrm{~d}$ & $7 \mathrm{~d}$ & $14 \mathrm{~d}$ \\
\hline G1 & 2.73E-08 & $6.09 \mathrm{E}+4$ & $3.21 \mathrm{E}+5$ & $3.67 \mathrm{E}+5$ & $2.25 \mathrm{E}+5$ & $9.50 \mathrm{E}+5$ & $5 \mathrm{E}+07$ & $6.38 \mathrm{E}+6$ \\
\hline G2 & $1.15 \mathrm{E}-08$ & $3.84 \mathrm{E}-08$ & 4.05E-08 & 5.49E-08 & $0.96 \mathrm{E}-07$ & 15.19 & 109.30 & 3241.1 \\
\hline G3 & $3.70 \mathrm{E}-08$ & $1.25 \mathrm{E}-07$ & $1.06 \mathrm{E}-07$ & $1.20 \mathrm{E}-07$ & $1.02 \mathrm{E}-07$ & \multicolumn{3}{|c|}{ All birds were died } \\
\hline
\end{tabular}




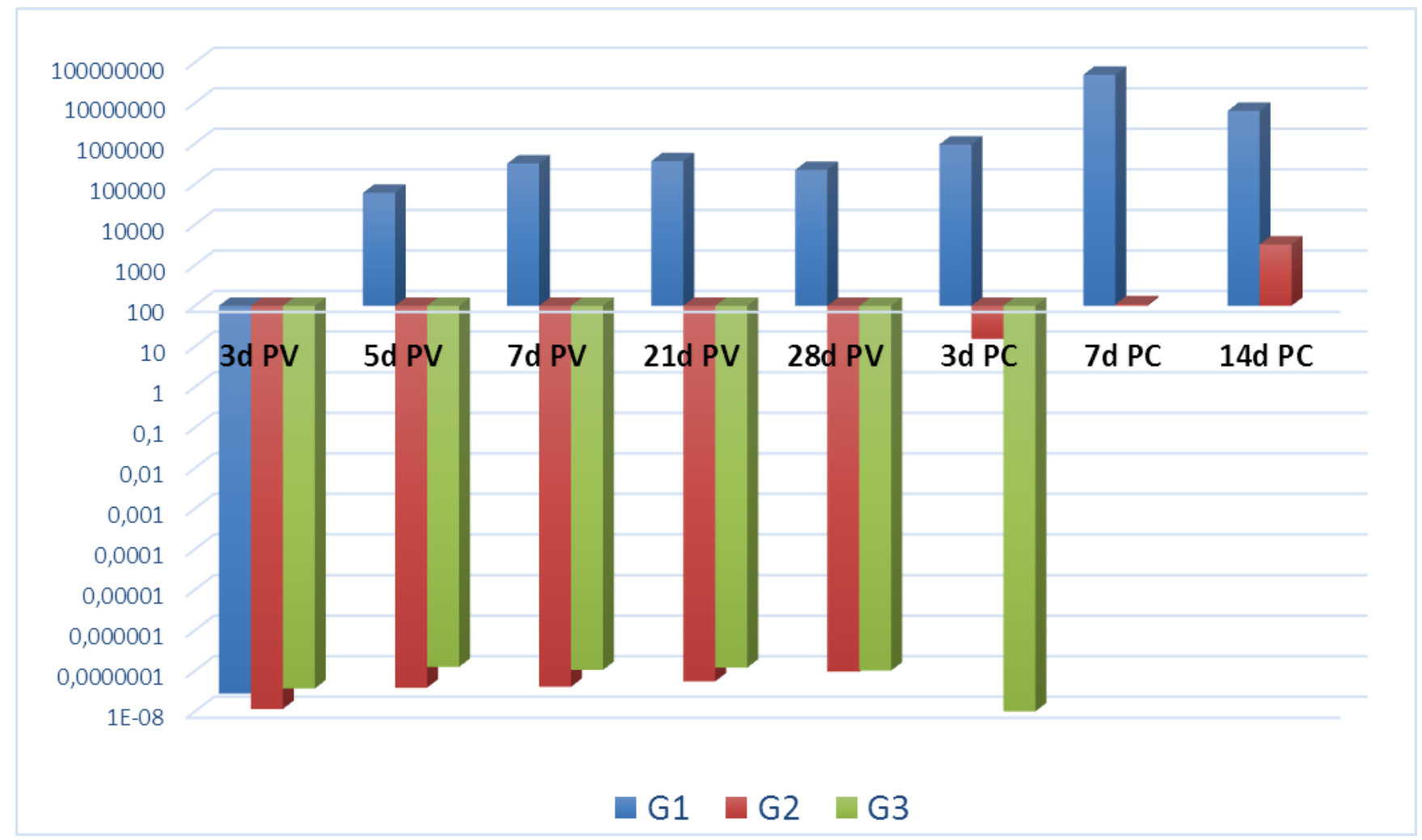

Fig. 6: IFN-gamma transcriptome profiling expressed as fold change of the birds receive DNA vaccine (G1), inactivated vaccine (G2) and the unvaccinated group (G3) post-vaccination (PV) and postchallenge (PC).

\section{DISCUSSION}

Eradication of avian influenza disease can be accomplished through strict adherent to the biosafety measures along with the use of massive vaccination. The vaccine must then afford two main properties, first should give a high level of protection plus minimize shedding to zero to eliminate environmental load and prevent secondary epidemics (Capua and Alexander 2007). Inactivated vaccines widely used does not ensure prevention of viral shedding due to its minimal capability to induce a cell-mediated immune response, a property that is favored by the DNA vaccine (Hsu, $\boldsymbol{e t}$ al., 2010 , Eman, 2014 and Maha, 2016).

In a previous study (Eman, 2014), we evaluated a DNA vaccine coding for the H5 gene. A high level of protection was achieved especially when adjuvented with esat- 6 of Mycobacterium tuberculosis as genetic adjuvant "immunomodulator" but the shedding level was still high, so in the current study we designed a DNA vaccine coding for $\mathrm{N} 1$ gene of circulating Egyptian field isolate (HPAI H5N1 subtype) and both protection and shedding levels were investigated.
The full-length N1 gene (orf) was amplified from the selected well-identified field strain (A/chicken/Qalubia/ch1.12.61/2017 (H5N1)). And cloned directionally in the cloning vector (pENTR $\left.{ }^{\mathrm{TM}} / \mathrm{SD} / \mathrm{D}-\mathrm{TOPO}\right)$ this method resulted in over than 200 colonies to be generated after $24 \mathrm{~h}$ incubation of the E.coli transformed host. Nearly all the tested colonies (using qPCR assay) had the recombinant donor vector $\mathrm{pENTR}{ }^{\mathrm{TM}} / \mathrm{SD} / \mathrm{D}-\mathrm{TOPO} / \mathrm{N} 1$.

Positive transformants were further sub-cloned, and a high purity level of plasmid purification using pure link HQ Mini Plasmid Purification Kit was done to perform the homologues recombination with destination vector $p$ DEST40. The expression vector pcDNA-DEST40 is a $7.1 \mathrm{~kb}$ vector derived from the pcDNA 3.1/V5-His vector and adapted for use with the Gateway Technology. It is designed to allow highlevel, constitutive expression of the gene of interest in a variety of mammalian hosts. pcDNA-DEST40 contains the essential elements for controlling the high level and selective expression of the gene insert in the mammalian cells including Human cytomegalovirus immediate-early (CMV) promoter/enhancer for highlevel expression (Boshart, et al., 1985) in a wide range of mammalian cells (Nelson, et al., 1987), Two 
recombination sites, attR1 and attR2, downstream of the CMV promoter for re-combinational cloning of the gene of interest from an entry clone to facilitate the homologues recombination, Chloramphenicol resistance gene located between the two attR sites for counterselection (Southern and Berg 1982). In addition, there is the ccdB gene located between the two attR sites for negative selection that resulted in cell death if the gene insert failed to be cloned in the destination vector. After analysis of the transformants, the maxiprep have been done and a high concentration of the plasmid was recovered $(450 \mu \mathrm{g} /$ litter overnight culture of pDEST40/N1.).

$p$ DEST 40/N1 DNA vaccine showed a very low protection rate of $(65 \%)$, although not surprising. The mechanism of virus entry relies on the H5 gene. Protection rate with the DNA vaccine coding for H5 generated in our Laboratory (Eman 2014) gave a higher rate of protection (88\%), especially when adjuvanted with immune-modulatory molecules ( esat 6). Such lower rate of protection noticed with DNA vaccine coding for $\mathrm{N} 1$ is mainly due to the fact that $\mathrm{H} 5$ gene is the main component in the avian influenza virus that is responsible for the cell entry and initiation of infection (Capua and Marangon 2007).

Another explanation to the inability of the pDEST40/N1 DNA vaccine to give acceptable protective rate is that the humoral immunity results, primarily, in the production of antibodies against viral glycoproteins NA and antibodies directed to HA prevent virus attachment to host cells and block receptor-mediated endocytosis, neutralizing virus infectivity. Whereas antibodies against NA produce "permissive immunity". HA (van de Sandt, et al., 2012)

On the other hand, the PM lesion was significantly different. DNA vaccine alone revealed no external sings on the dead birds (G1) like cyanosis of the combs and very few hemorrhagic spots on the coronary fat along with no congestion of the lungs and slight congestion of tracheas. The study of Nayak, et al., (2010) find that Immunization with HA or NA induced high titers of neutralizing antibodies, with the response to HA being more significant, thus identifying HA and NA as independent neutralization antigens. Immunization with $\mathrm{HA}$ alone or in combination with NA induced complete protection against HPAIV challenge. Immunization with NA alone or in combination with M2 did not prevent death following challenge but extended the period before death

One of the very important outcomes of the use of pDEST40/N1 DNA vaccine was the control of the shedding. The shedding seen in the group vaccinated with the pcDEST40/N1 had an EID $_{50}$ of $0.46 \log 10$ which is about $5 \log 10$ decrease than that of the control non-vaccinated chicks which are near the ideal parameter of any desired vaccine (standard Egyptian regulation for evaluation of vet. biologics, CLEVB V2 2009). The other surprising data obtained from the current study was the ability of the DNA vaccine coding for $\mathrm{N} 1$ gene to eliminate the shedding from the infected but recovered chickens (EID ${ }_{50}$ of zero $\left.\log 10\right)$. These findings can be explained by the permissive effect of NA antibodies that can block the release of infectious virions from the apical surface of infected cells, and lessens viral spread.

The concept of permissive immunity afforded by NA antibodies was initially characterized in laboratory animal models of disease, and in humans recovering from disease (Marcelin et al.,2012, Memoli et al.,2016, padilla-quirarte et al.,2019), in these studies, the addition of NA antisera from convalescent humans failed to block infection of cells in vitro, but in mice NA antibody can reduce morbidity and mortality, shortening the severity and duration of the disease (Matrosovich, et al., 2004 and van de Sandt, et al., 2012). Another explanation for the minimizing shedding level to zero is based on the ability of the DNA vaccine coding for the $\mathrm{N} 1$ gene to induce a high level of IFN- $\gamma$ that block viral replication after cell entry and hence reduce mature virions

\section{CONCLUSIONS}

From the current study, it can be oncluded that, the DNA vaccine coding for $\mathrm{N} 1$ gene failed to give the recommended rate of protection but found to be superior in preventing virus shedding in live birds after infection and severely decrease shedding from dying and dead birds. Combination of DNA vaccine coding for N1 with that coding for H5 could be a promising step to ensure maximum protection with zero shedding.

\section{REFERENCES}

BARMAN S, ADHIKARY L, CHAKRABARTI AK, BERNAS C, KAWAOKA Y AND NAYAK DP.2004.

Role of Transmembrane Domain and Cytoplasmic Tail Amino Acid Sequences of Influenza A Virus Neuraminidase in Raft Association and Virus Budding Journal of Virology 78(10):5258-69

BLUMENKRANTZ D, KIM L, ROBERTS HS, SAMANTHA L, BARCLAY WS. 2013. The Short Stalk Length of Highly Pathogenic Avian Influenza H5N1 Virus Neuraminidase Limits Transmission of Pandemic H1N1 Virus in Ferrets. Journal of Virology (87) p. $10539-10551$

BOSHART M, WEBER F, JAHN G, DORSCHHÄSLER K, FLECKENSTEIN B AND SCHAFFNER W.1985. A Very Strong Enhancer is Located Upstream of an Immediate Early Gene of Human Cytomegalovirus. Cell. 41(2):521-530 
CAPUA I AND ALEXANDER DJ.2007. Avian influenza: recent development.Avian pathol, 33(4):393-404.

CAPUA I AND MARANGON S. 2007. Control and prevention of avian influenza in an evolving scenario. Vaccine. 26(30):5645-5652

CHEN YQ, WOHLBOLD TJ, ZHENG NY, HUANG M, HUANG Y, NEU KE, ET AL.2018. Influenza infection in humans induces broadly cross-reactive and protective neuraminidase-reactive antibodies. Cell. 173:417-29 e10. doi: 10.1016/j.cell.2018.03.030

EMAN MS EL-NAGAR. 2014. Study of the immunopotentiation effect of Esat-6 of Mycobacteria on DNA vaccine encoding the $\mathrm{H} 5$ gene of avian influenza virus. $\mathrm{PhD}$ thesis, Vet. Collage, Cairo University.

FLYNN KJ ET AL. 1999. In vivo proliferation of naive and memory influenza-specific CD8 (+) T cells. Proc Natl Acad Sci USA 96(15):8597-8602

FOUCHIER R, MUNSTER VA, WALLENSTEN T, BESTEBROER S, HERFST D, SMITH G, RIMMELZWAAN B, OLSEN A AND OSTERHAUS .2005. Characterization of a novel influenza A virus hemagglutinin subtype (H16) obtained from black-headed gulls, J. Virol. 79 28142822

GUO H, KUMAR P AND MALARKANNAN S .2011. Evasion of natural killer cells by influenza virus. J Leukoc Biol. 2011 Feb; 89(2): 189-194

PADILLA-QUIRARTE HO, DELIA V. LOPEZGUERRERO, LOURDES GUTIERREZXICOTENCATL AND FERNANDO ESQUIVELGUADARRAMA1.2019.Protective Antibodies against Influenza Proteins. Front. Immunol., 182019 | https://doi.org/10.3389/fimmu.2019.01677

HARRIS KA, FREIDL G S, MUNOZ O S, VON DOBSCHUETZ S, DE NARDI M AND WIELAND B, ET AL. 2017. Epidemiological risk factors for animal influenza A viruses overcoming species barriers. EcoHealth 14, 342-360.

HONG YH, LILLEHOJ HS, LILLEHOJ EP AND LEE SH. 2006. Changes in immune-related gene expression and intestinal lymphocyte subpopulations following Eimeria maxima infection of chickens. Vet. Immunol. Immunopathol. 114(3-4): 259-272.

HSU SM, CHEN TH AND WANG CH .2010. Efficacy of Avian Influenza Vaccine in Poultry: A Meta-analysis. Avian Diseases: 54, (4), 1197-1209

JALILIAN B, ABDUL RAHMAN OMAR, BEJO MH, ALITHEEN NB, RASOLI M AND SOHKICHI MATSUMOTO .2010. Development of avian influenza virus H5 DNA vaccine and MDP-1 gene of Mycobacterium bovis as genetic adjuvant Genet Vaccines Ther. , 8: 4

KAISER P, UNDERWOOD G AND DAVISON F. 2003. Differential Cytokine Responses following Marek's Disease Virus Infection of Chickens Differing in Resistance to Marek's Disease. J. of Virol. 77. (1): 762-768

KIM C, LEW W, WILLIAMS M, LIU H, ZHANG L, SWAMINATHAN S, BISCHOFBERGER $\mathbf{N}$, CHEN M, MENDEL D, TAI C, LAVER W AND STEVENS R. 1997. Influenza neuraminidase inhibitors are possessing a novel hydrophobic interaction in the enzyme active site. Design, synthesis, and structural analysis of carbocyclic sialic acid analogues with potent anti-influenza activity, J. Am. Chem. Soc. 119:681-690.

LEITNER WW, SEGUIN MC BALLOU WR, SEITZ JP, SCHULTZ AM, SHEEHY MJ AND LYON JA .1997. Immune responses induced by intramuscular or gene gun injection of protective deoxyribonucleic acid vaccines that express the circumsporozoite protein from Plasmodium berghei malaria parasites. J Immunol.159:6112-6119

LIMA KM, SANTOS SA, LIMA VMF, COELHOCASTELO AAM, RODRIGUES JM AND SILVA CL.2003. Single dose of a vaccine based on DNA encoding mycobacterial HSP65 protein plus TDMloaded PLGA microspheres protects mice against a virulent strain of Mycobacterium tuberculosis. Gene Therapy.; 10(8):678-685. doi: 10.1038/sj.gt.3301908

MAHA AN GAMAL. 2016. Production and Evaluation of DNA vaccine coding for Neuraminidase N1 gene against avian influenza H5N1. PhD thesis, Vet. Faculty, Alexandria University.

MARCELIN G, SANDBULTE M AND WEBBEY .2012. Contribution of antibody production against neuraminidase to the protection afforded by influenza vaccines. Reviews in Medical Virology 22(4):267-79 .

MATROSOVICH MN ET AL. 2004. Neuraminidase is important for the initiation of influenza virus infection in human airway epithelium. J Virol 78(22):1266512667

MCAULEY JL, GILBERTSON BP, TRIFKOVIC S, BROWN LE AND MCKIMM-BRESCHKIN JL. 2019. Influenza Virus Neuraminidase Structure and Functions. Front Microbiol. 10: 39

MEMOLI MJ, SHAW PA, HAN A, CZAJKOWSKI L, REED S, ATHOTA R, ET AL.2016. Evaluation of antihemagglutinin and antineuraminidase antibodies as correlates of protection in an influenza $\mathrm{A} / \mathrm{H} 1 \mathrm{~N} 1$ virus healthy human challenge model. MBio. 7:e00417-16. doi: $10.1128 / \mathrm{mBio} .00417-16$

NAKSUPAN N,SANGUANSERMSRI D, WONGVILAIRAT $R$, NIUMSUP P, PONGCHAROEN S,CHAMNANPOOD $P$, CHAMNANPOOD C AND SANGUANSERMSRI P. 2008. Whole-genome sequences of $\mathrm{h} 5 \mathrm{n} 1$ influenza $A$ virus isolated from a little grebe in Thailand. Southeast Asian J. Trop Med Public Health, 39 (3): 373- 382

NAYAK B, KUMAR S, DINAPOLI JM, PALDURAI A, PEREZ DR, COLLINS PL AND SAMAL SK. 2010. Contributions of the Avian Influenza Virus HA, NA, and M2 Surface Proteins to the Induction of Neutralizing Antibodies and Protective Immunity. J Virol. 84(5): 2408-2420

NELSON J A, REYNOLDS-KOHLER C, AND SMITH BA. 1987. Negative and Positive Regulation by a Short Segment in the 5'-Flanking Region of the Human Cytomegalovirus Major Immediate-Early Gene. Molec. Cell. Biol. 7: 4125-4129.

PETE K, GREG U.AND FRED, DAVISON .2003 Differential Cytokine Responses following Marek's Disease Virus Infection of Chickens Differing in Resistance to Marek's Disease J. Virol, 77, (1): 762768 
REED LJ AND MUENCH H. 1938. A simple method of estimating fifty per cent endpoints. American Journal of Epidemiology, 27, (3): 493-497.

SAMBROOK J, FRITSCH EF AND MANIATIS T. 1989. Molecular cloning: A laboratory manual, 2nd ed.Cold Spring Harbor Lab., N.Y.

SCHMITTGEN TD AND LIVAK KJ. 2008. Analyzing real-time PCR data by the comparative $\mathrm{Ct}$ method. Nature Prot. 3:1101-1108.

SOLIMAN YA, MAHA A GAMAL AND KHALIL SA .2016. Generation of Plasmid Vector Coding for Neuraminidase Gene NA1 of Highly Pathogenic Avian Influenza H5N1 Subtype. Alexandria Journal of Veterinary Sciences; 51(2): 101-111

SOUTHERN P J, AND BERG P. 1982. Transformation of Mammalian Cells to Antibiotic Resistance with a Bacterial Gene under Control of the SV40 Early Region Promoter. J. Molec. Appl. Gen. 1:327-339.

SYLTE MJ AND SUAREZ DL.2009. Influenza Neuraminidase as a Vaccine Antigen Curr Top Microbiol Immunol. 333:227-41

TONG S, ZHU X, LI Y,SHI M, ZHANG J AND BOURGEOIS M ET AL. 2013. New world bats harbour diverse influenza A viruses. PLoS Pathog. 9. E1003657

VAN DE SANDT C E, KREIJTZ J H RIMMELZWAAN G F. 2012. Evasion of influenza A

How to cite this article:

Soliman Y.A., Maha A.N. Gamal, Eman M.S. Elnagar and Khalil, S.2020. The Immunogenicity And Protective Efficacy Of Dna Vaccine Coding For Na1 Gene Of Highly Pathogenic Avian Influenza H5n1 Subtype. Journal Of Applied Veterinary Sciences, 5(2): $108-123$.

DOI: HTTPS://DX.DOI.ORG/10.21608/JAVS.2020.85638 viruses from innate and adaptive immune responses. Viruses. 4(9):1438-76.

WEBSTER R, BEAN W, GORMAN O, CHAMBERS T AND KAWAOKA Y. 1992. Evolution and ecology of influenza A viruses, Microbiol. Rev. 56 () 152-179.

WILEY JA ET AL. 2001. Antigen-specific CD8 (+) T cells persist in the upper respiratory tract following influenza virus infection. J Immunol 167(6):3293-3299

YEONG HH, HYUN SL, SUNG HL, RAM AD AND ERIK PL. 2014. Analysis of chicken cytokine and chemokine gene expression following Eimeria acervulina and Eimeria tenella infections. Veterinary Immunology and Immunopathology 114: 209-223 